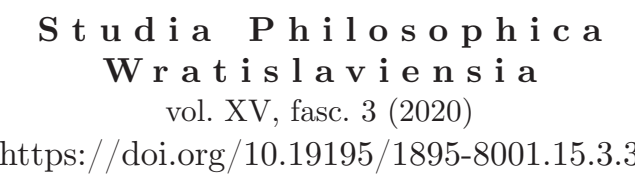

\author{
AGNIESZKA BANDURA \\ ORCID: 0000-0002-6854-7008 \\ Uniwersytet Wrocławski
}

\title{
Wszystko albo nic — abstrakcyjna geneza sztuki
}

\section{Everything or nothing — abstract genesis of art}

\begin{abstract}
In this paper I present the specific issues of contemporary abstract art, which negated the classic mimetic categories of resemblance and original (originary), but nevertheless does not lack any reference (Goodman). I focus on the questions of the beginning, history and evolution as well as the contemporary genres of abstract art (Kandinsky, Malevich, Reinhardt and others), trying to show that the answers to the questions very often take form of panaesthetic and universal statements ("everything") or exclusionary negations ("nothing"). Describing the contemporary abstract art I base on two - characteristic to it - concepts of anti-purism (a critic of so called "pure art") and the strategy of object oversizing ("size matters").
\end{abstract}

Keywords: abstraction, representation, evolution, timeless, purism, "size matters"

Współczesna sztuka abstrakcyjna (malarstwo, grafika, rzeźba, fotografia, film, animacja itp.) nieodwracalnie podważyła obecne w klasycznej teorii mimesis kategorie podobieństwa oraz oryginału. Sztuka przestaje odtwarzać rzeczywistość. „Dzieło sztuki plastycznej nie wyraża nic. Dzieło sztuki nie jest znakiem czegokolwiek. Ono jest (istnieje) samo przez się"2. Rezygnacja z podobieństwa nie oznacza jednak, że sztuka abstrakcyjna traci wszelką referencyjność — wciąż odnosi się o ile nie do szczególnych elementów czy własności siebie samej, to do swej istoty, genezy oraz funkcji względem odrzuconej, zbędnej czy nieistotnej rzeczywistości.

\footnotetext{
${ }^{1}$ E. Chillida, Writings, Düsseldorf 2009, s. 49.

${ }^{2}$ W. Strzemiński, O nowej sztuce, „Blok” 2 (1924).
} 
Czy o tak rozumianej fundamentalnej postaci sztuki można mówić w sposób nowy, niepodobny, wcześniej nie napotkany w żadnym z idących w nieskończoność tomów, teorii, opracowań „odwiecznego" tematu abstrakcji? Nie wydaje mi się — wartościowa, godna uwagi refleksja na temat abstrakcji w sztuce zawsze naznaczona jest istotnym defektem: jej punkt wyjścia jest panestetyczny i/ lub panartystyczny (każda sztuka jest, przynajmniej u źródeł, abstrakcyjna i konceptualna; współczesne abstrakcjonizmy to tylko inne warianty zgranego tematu) bądź z konieczności autoteliczny i hermetyczny (akwarele Kandyńskiego czy obrazy Malewicza to innowacja zupełna - nieprzedstawieniowość wystrzeliła awangardę poza orbitę historii sztuki zachodniej, sama abstrakcja wymyka się tak percepcji, jak rozumieniu, językowi, interpretacji itp.). Pierwsze z podejść wydaje się zbyt ogólne, dodatkowo na granicy możliwości czy kompetencji niejednego estetyka lub historyka sztuki; drugie z kolei — zbyt fragmentaryczne, „oderwane”, nicujące relacje abstrakcjonizmu tak z historią, jak z innymi formami sztuki.

W obliczu abstrakcji stajemy przed alternatywą: wszystko albo nic.

Konieczne wydają się zatem rozstrzygnięcia radykalne — również wobec pytania o pojawienie się i rozwój abstrakcji w historii sztuki w ogóle. Tu kolejna alternatywa przedstawia się następująco: albo zakładamy, że progres w abstrakcji nie ma racji bytu — nie może być mowy o postępie czy kumulacji wiedzy płynącej z doświadczenia, eksperymentów, transformacji paradygmatów itp., początek jest końcem itp.; albo stajemy po stronie rozwoju, ewolucji abstrakcyjnych form sztuki, która ukoronowanie znajduje w niefiguratywnej czy bezprzedmiotowej praktyce współczesnych awangard pierwszej i/lub drugiej połowy XX wieku. Jednak nawet jeśli założymy, że mimo pozornie nowatorskiego charakteru awangardy abstrakcja jest ,stara jak świat", wciąż pozostaje problem genezy sztuki z abstrakcji czy, mówiąc bardziej ogólnie, z ludzkiej zdolności abstrahowania (wraz z hipotezą, że abstrakcja jest starsza od sztuki - leży u jej źródeł). Innymi słowy, czy abstrakcja stanowi warunek tworzenia i jako taka wyprzedza sztukę (sztuki) w ogóle, czy przeciwnie - Malewiczowski Czarny kwadrat wieńczy dzieło stworzenia, po którym już tylko szabat?

W artykule tym chciałabym nakreślić możliwe sposoby odpowiedzi na te pytania, jak również wskazać na specyfikę sztuki abstrakcyjnej, wypływającą z modernistycznego mitu puryzmu przedstawienia oraz z niespotykanej przed połową dwudziestego wieku strategii „przeskalowania” obiektu estetycznego (,size matters”).

\section{1 ponadczasowość a istotowa genetyczność abstrakcji (inaczej źródłowość)}

The beginning in art is not the beginning ${ }^{3}$

W 1965 roku Ad Reinhardt, ironizując na temat pomysłu rozwoju czy historii sztuki w ogóle oraz obowiązującej w niej progresji, w notatce roboczo i przewrot-

${ }^{3}$ A. Reinhardt, Art in Art is Art-as-art (Art-as-Art Dogma III), [in:] Art-as-Art. The Selected Writings of Ad Reinhardt, B. Rose (ed.), Berkeley LA 1991, s. 63 (w tłumaczeniu autorki — również pozostałe cytaty z tego dzieła).

Studia Philosophica Wratislaviensia, vol. XV, fasc. 3 (2020)

(C) for this edition by CNS 
nie zatytułowanej Pięć stadiów cyklu rozwoju ponadczasowego stylu Reinhardta tak kuriozalnie opisał ewolucję własnej twórczości od lat trzydziestych do sześćdziesiątych XX wieku:

a. Późnoklasyczne manierystyczne postkubistyczne abstrakcje geometryczne z późnych lat 30 .

b. Rokokowo-półsurrealistyczna fragmentacja sztuki i geometryczno-ekspresjonistyczne formy all over

c. Archaiczny „pędzlowy” impresjonizm barw i kostek oraz Czarno-biała kaligrafia konstruktywistyczna późnych lat 40.

d. Wczesnoklasyczne hieratyczne symetryczne formy z czerwonych, niebieskich, czarnych monochromatycznych krzyżujących się promieni z lat 50 .

e. Klasyczne jednolite czarno-kwadratowe ponadczasowe półtorametrowe tryptykowe ulotności z lat 60 .

Dodając pod spisem etapów jeszcze dwie uwagi:

Jak bardzo musimy zanurzyć się w ciemności, by zaakceptować zgodność przeciwieństw, by szukać prawdy w obliczu niemożliwości.

- Mikołaj z Kuzy

„nasi przyszli czytelnicy należeć będą do cywilizacji bardziej wyszukanej i subtelnej niż jakakolwiek wcześniej"4.

Ad Reinhardt znany był zarówno z autoironicznego stosunku do samego siebie, jak i do aktualnych praktyk artystycznych wraz z towarzyszącymi im teoriami. Szczególnie bliska była mu oświeceniowa misja objaśniania sztuki abstrakcyjnej — w komiksowej historyjce z 1945 roku o jej przypadkowym odbiorcy abstrakcyjna kompozycja wyciąga groźne łapska po chichoczącego widza, wrzeszczac: „A ty co sobą reprezentujesz?!".

Autorefleksyjne podejście do sztuki doprowadziło go — już zupełnie serio do koncepcji ,sztuki aczasowej”. Ogłoszony w 1963 roku manifest timeless art był w rzeczywistości apelem o radykalne przebudowanie zarówno samego pojęcia sztuki, jak i rządzacych nią podstawowych reguł - i to wbrew awangardowej tradycji, która zakładała koniecznie oryginalną innowację czy nowość z „obsesyjnym” w sztuce zachodniej przekonaniem o dokonującym się w niej postępie. Analogiczną krytykę tradycyjnej historii sztuki — czy to linearnej, czy cyklicznej — opartej na idei postępu oraz upadku i odrodzenia forsowali przed artystą, między innymi George Kubler czy Lewis Mumford.

W dwunastym dogmacie „sztuki-jako-sztuki”, opublikowanym w „Artforum” w marcu 1966, Ad Reinhardt podsumowywał:

There is just one art, one art-as-art.

There is just one fine art, one abstract art, one free art.

$[\ldots]$

There is just one painting everytime ${ }^{5}$.

Koncepcję sztuki aczasowej płynnie uzgodnił z powtarzaną w rozmaitych odsłonach ideą ,art-as-art”, która jest celem wszelkiej rewolucji w sztuce, a użyta

\footnotetext{
4 A. Reinhardt, [notatka bez tytułu z 1965 roku], [in:] ibidem, s. 10.

5 A. Reinhardt, There is Just One Painting (Art-as-Art Dogma XII), [in:] ibidem, s. 70-71.
} 
tu liczba pojedyncza jest najwłaściwsza — w sztuce mamy do czynienia z jedną, permanentną, od/wieczną rewolucją ${ }^{6}$.

Jedna sztuka, bez początku i końca, w każdej swej szczegółowej emanacji cała, zupełna, bez względu na wygląd czy odbiór autentyczna, o ile tylko tworzona z myślą o samej sobie, a nie innych celach. Sztuka bez historii — obca jest jej idea postępu, którego ukoronowanie stanowiło według tak wielu malarzy awangardowych „wynalezienie abstrakcji” w pierwszej połowie XX wieku (Władysław Strzemiński dał wyraz takiemu podejściu w Teorii widzenia: abstrakcjonizm jest najbardziej rozwiniętą formą sztuki, a wymagane przez niego ,widzenie empiryczne" winduje ludzką percepcję na czwarty - po widzeniu konturowym, sylwetowym i bryłowym — najwyższy poziom).

Parafrazując to motto: wyłącznie pozornie - dla porządku bądź z poczucia przyzwoitości dla linearnej wizji historii - zaczynamy od początku. Ad Reinhardt obnaża sam początek w sztuce jako asekuracyjny sztuczny koncept, podobnie jak idee przełomu czy przewrotu — pozorny, dodatkowo zdublowany, wynalazek wpierw nowożytności, potem awangardy. Pozostawiając w mocy jedynie ideę końca-celu, którym od zawsze jest sztuka sama czy sztuka-jako-sztuka.

Wizja sztuki, która w każdym swym momencie jest „nierozwojowa” — zupełna, w doskonałym rozwinięciu bądź ,zerowa”, w optymalnym zwinięciu — leży u podstaw wielu współczesnych teorii estetycznych. W naturalny sposób unieważnia współczesny podział na sztukę przedstawiającą i nieprzedstawiającą, zwaną abstrakcyjną (traktowaną jako jedną z najbardziej oczywistych awangard, to jest najnowszy czy najbardziej aktualny etap w rozwoju sztuki zachodniej). ,Sztuka zawsze jest abstrakcyjna"7 — pisała Susanne K. Langer, mając na myśli, że każdy artefakt jest poprzedzany konceptem i aktami refleksji oraz przemyślanych wyborów; że autentyczne dzieło sztuki powinno być rezultatem procesu odnoszenia się do- bądź refleksji nad zapoczątkowującym je pierwotnym impulsem. Nic bardziej oczywistego - w podobny sposób uzasadniali podniesienie malarstwa, rzeźby czy architektury z poziomu artes vulgares do sztuk wyzwolonych renesansowi artyści i teoretycy: namysł, refleksja, koncepcja, wizja (disegno) wyprzedzają realizację, wykonanie.

Sztuka jest zatem zawsze abstrakcyjna - wymaga przemyśleń, oparta jest na pojęciu, daje do myślenia. W jaki jednak sposób uzasadnić uprzywilejowaną pozycję abstrakcjonizmu — jako formy ekspresji najbardziej uniwersalnej, ogólnej, po kantowsku bezinteresownej itp. — pośród rozmaitych form wyrazu artystycznego? Nie sposób uciec - w związku z ahistorycznością czy aczasowością sztuki — od pytania o fundamentalne (istotowe) pierwszeństwo genetyczne abstrakcji, inaczej jej źródłowość. Francuscy estetycy fenomenologiczni, Maurice Merleau-Ponty i Mikel Dufrenne, zwykli używać na określenie tego pierwotnego stanu (nierozróżnialności tego, co staje się, co się wydarza i jest przed-stawione; inaczej zmieszania czy

${ }^{6}$ A. Reinhardt, The Next Revolution in Art (Art-as-Art Dogma II), [in:] ibidem, s. 59.

7 S.K. Langer, Abstraction in Science and Abstraction in Art, [in:] S.K. Langer, Problems of Art, New York 1957, s. 163. 
„kom-unii” podmiotu i rzeczy/ świata) dwóch adekwatnych terminów: originaire i présence.

Pierwszy, originaire, dehistoryzuje sztukę, wskazując na każdorazowo obecny w doświadczeniu estetycznym wspólny grunt, zakorzenienie czy genezę człowieka i obrazu; ponadto zawiesza kwestię heterogeniczności sztuki mimetycznej i abstrakcyjnej - Maurice Merleau-Ponty wielką inspirację teorii źródłowości doświadczenia sztuki znajduje w malarstwie Cézanne'a, ale jeszcze dobitniej wybrzmiewa tu filozofia Klee z Confession créatrice z 1920 roku: „sztuka nie odtwarza widzialnego, lecz pozwala zobaczyć" („l'art ne reproduit pas ce qui est visible mais rend visible"). Estetycy i artyści pierwszej połowy XX wieku kładą nacisk na pierwotny, źródłowy, archaiczny (originaire porównać wszak można do starożytnej arché będącej przyczyną, zasadą i celem doświadczenia czy poznania) charakter sztuki impresjonistycznej, postimpresjonizmu, kubizmu czy wreszcie abstrakcjonizmów. Mikel Dufrenne zwraca uwagę na słabość czy niewystarczalność racjonalnych środków językowych cogito dla opisu takiego pierwotnego stanu doświadczania tego, co źródłowe, tego, co ,surowe” (originaire, l’être brut) — gdy nie ma jeszcze rozdźwięku (hiatus) między człowiekiem i rzeczami, gdy „rzeczy są [jeszcze] sekretnymi fałdami mojego ciała"8; stanu, w którym podmiot jest w harmonii z rzeczami, gdy „jestem wyłącznie refleksją fenomenu", gdy ,jestem tym, co widzę", ale zarazem widzę to, czym jestem, do czego pierwotnie przynależę itp.

Drugi aspekt, présence (obecność), odnosi się do specyficznego dla doświadczenia sztuki wstępnego etapu percepcji (obecność wyprzedza tu zarówno przedstawienie, jak refleksję): bezpośredniego doznania obecności konkretnego, lecz danego w pełni, zmysłowego istnienia przedmiotu przez świadomość przedrefleksyjną.

$\mathrm{Na}$ tym pierwszym etapie (ujmowania obecności — présence) bezpośrednio doświadczamy tego, co zmysłowe wraz z nieoddzielnym od niego żywym sensem (nie czyniąc sztucznego rozróżnienia na rzecz i jej znaczenie) ${ }^{10}$. Na tym przedrozumowym etapie rzeczy i ludzie (przedmiot/ świat i podmiot/y) sac w równym stopniu obecni/równocześni (présents) sobie i w świecie. Jeszcze inaczej, na planie obecności rzeczy są dane, lecz nie są (roz)poznane czy bardziej dobitnie: ,przed-

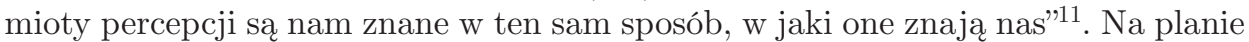
obecności jesteśmy w świecie rozumianym jako całość (totalité) jeszcze nie rozdzielona na podmioty i przedmioty. Doświadczenie obecności opisuje Mikel Dufrenne jako „doświadczenie szczęśliwe” czy jako „otwarcie, jakby wskutek uderzenia, świata bezpośrednio dostępnego i bliskiego"12, będące „poza wszelkimi dowodami i wszelkimi wyjaśnieniami”"13, ze specyficzną jednak dla siebie „racjonalnością” ( une

${ }^{8}$ M. Dufrenne, In the Presence of the Sensuous, transl. M.S. Roberts, D. Gallagher, Atlantic Highlands 1990, s. 72 .

${ }^{9}$ Ibidem, s. 111.

${ }_{10}$ M. Dufrenne, Sztuka i natura, tłum. I. Wojnar, [w:] Antologia współczesnej estetyki francuskiej, I. Wojnar (red.), Warszawa 1980, s. 457.

11 Ibidem, s. 482.

12 Ibidem, s. 457.

13 Ibidem. 
intelligibilité propre $)^{14}$. Nie sposób tu uciec od analogii z Baumgartena wizją doświadczenia (poznania zmysłowego - cognitio sensitiva), możliwemu dzięki „estetycznemu fartowi" (fucus aestheticus), w którym przedmiot zmysłowy objawia się w pełni naraz (ubertas aesthetica), i nie pozbawionego porządku analogi rationis ${ }^{15}$. Czy od wyraźnie zainspirowanej tak baumgartenowską estetyką, jak francuską fenomenologią estetyczną, ponadczasowej i transkulturowej oraz dowartościowującej cielesność/zmysłowość koncepcji „estetyki ponad estetyką” (aesthetics beyond aesthetics) Welscha ${ }^{16}$.

Dehistoryzacja, to jest oczyszczenie kwestii sztuki abstrakcyjnej z wątku czasu, historii, początku itp., oddala też jakże kłopotliwą kwestię „wynalezienia” abstrakcji (jak powszechnie wiadomo, do miana jej demiurgów pretenduje coraz liczniejsze grono artystek i artystów). I kolejną, być może jeszcze bardziej kłopotliwą, sprawę klasyfikacji i sztucznych (?) podziałów sztuki abstrakcyjnej na analityczną, ekspresyjną, organiczną itp., o której na kolejnych stronach.

Spory o „wynalezienie" sztuki abstrakcyjnej sięgają (co najmniej) przełomu XIX i XX wieku (polemika toczy się oczywiście najżywiej w pierwszych dekadach wieku XX). Choć wielu artystów współczesnych hołduje ahistorycznej definicji abstrakcji podanej przez Langer (abstrakcja cechować ma wszelką twórczość jako odchodzącą od szczegółu do ogółu, opartą na obmyślaniu), wciąż nie ustają dywagacje na temat twórcy czy twórczyni pierwszego dzieła abstrakcyjnego. Palmę pierwszeństwa dzierżą na przemian legendarny Alphonse Allais (jeden z liderów predadaistycznej grupy Les Arts Incohérents, działającej w Paryżu w latach osiemdziesiątych i na początku dziewięćdziesiątych XIX wieku) bądź bardziej anonimowy Paul Bilhaud (członek tegoż ugrupowania) z pokazanym w 1882 i 1897 roku „czarnym prostokątem”, zatytułowanym Nocna walka murzynów w tunelu (Combat de nègres dans un tunnel pedant la nuit) — obraz ten mógł być inspiracją czarnego kwadratu Malewicza (1915), o ile ten ostatni go znał ${ }^{17}$. Słynny obraz Malewicza, Czarny suprematyczny kwadrat (zwany też Czarnym kwadratem na białym tle), antydatowany przez niego na 1913 rok $^{18}$, powstał prawdopodobnie w roku 1915 , a światło dzienne ujrzał podczas pierwszej wystawy suprematyzmu (w ramach ostatniej wystawy futurystów, jakkolwiek zaskakująco by to brzmiało) w grudniu tegoż roku.

Jeszcze bardziej znana i nagłośniona medialnie na przełomie XX i XXI wieku jest rywalizacja o pierwszeństwo między dwojgiem innych abstrakcjonistów: af Klint — Szwedką, autorką wielkoformatowych, odsyłających do sfery duchowości abstrakcyjnych akwareli i gwaszy, które zaczęła malować około 1906-1907 roku, a Kandyńskim — autorem nietytułowanej akwareli abstrakcyjnej z 1910 roku oraz

14 Por. M. Dufrenne, La poétique, précedé de Pour une philosophie théologique, Paris 1972, s. 2.

15 Por. A.G. Baumgarten, Aesthetica, Frankfurt/Oder 1750-1758.

${ }^{16}$ Por. W. Welsch, Estetyka poza estetyka. O nowa postać estetyki, tłum. K. Guczalska, Kraków 2005.

17 W 2015 roku świat sztuki obiegła rewelacyjna wiadomość o odkryciu przez restauratorów Galerii Tretiakowskiej widocznego w krakelurach obrazu napisu „Bitwa czarnych w ciemnej jaskini”.

18 Por. A. Shatskikh, Black Square. Malevich and the Origin of Suprematism, transl. M. Schwartz, New Haven-London 2012. 
Obrazu z okręgiem z 1911 roku (tu też nie ma zgodności w kwestii, które z dzieł jest pierwszym obrazem abstrakcyjnym Kandyńskiego). W latach 1910 i 1911 Wasyl Kandyński stworzył też wiele inspirowanych muzyką, abstrakcyjnych Improwizacji, następnie numerowanych Kompozycji - w podobnym czasie Hilma af Klint zaczęła wprowadzać do swoich ekspresjonistyczno-abstrakcyjnych obrazów elementy geometryczne.

Ale to nie kres wątpliwości w kwestii „wynalezienia” abstrakcji — analizując odkrycia sztuki awangardowej pierwszych dwóch dekad XX wieku, nie sposób pominąć Litwina Čiurlionisa (jego częściowo abstrakcyjnych Sonat z lat 1907-1910); futurokubistycznych eksperymentów Picabii (jak Caout-chouc z 1909 roku, La Source czy Wiosennego tańca z 1912 roku, zaprezentowanych na Armory Show niespełna rok później); w latach 1912-1913 Paul Klee zwraca się ku „czystemu malarstwu”, a w 1914 rozpoczyna się u niego okres ,abstrakcji mistycznej”, niewielkich rysunków oraz akwareli, w których widać artysty (wyjątkowo trudnego do ,zaszufladkowania” ze względu na wszechstronność poszukiwań artystycznych, jak bogactwo stosowanych technik) zmagania z figuratywnością; w latach 1916-1917 Hans Arp prezentuje serię abstrakcyjnych, diagonalnych i opartych na kwadratach kompozycji (jak Kwadraty ułożone według przypadkowych praw i innych, bez tytułów).

Nie można też zapomnieć o abstrakcyjnym elementach i podstawach kubizmu (głównie na jego etapie analitycznym i hermetycznym, to jest do 1912 roku), futuryzmu, neoplastycyzmu oraz konstruktywizmu... W odniesieniu do pierwszych dekad XX wieku mówić można wręcz o zjawisku „odkrycia równoczesnego” sztuki abstrakcyjnej, które dokonało się za sprawą przedstawicieli rozmaitych nurtów sztuk wizualnych (nie tylko malarstwa, lecz również rzeźby, projektowania, fotografii, animacji, filmu itp.) oraz z rozmaitych pobudek i dla różnych celów.

Oczywiście w poszukiwaniach początków sztuki abstrakcyjnej cofnąć można się jeszcze dalej, aż do starożytności — podobno pierwszy obraz (rysunek) abstrakcyjny powstał (raczej przez przypadek) w IV wieku p.n.e. Pliniusz Starszy w Historii naturalnej opisuje pojedynek dwóch utalentowanych malarzy, Apellesa i Protogenesa, rywalizujących o to, który namaluje jak najcieńszą kreskę. Obraz — wedle relacji Pliniusza - był szeroko znany i ceniony za precyzję wykonania... ${ }^{19} \mathrm{~W}$ średniowiecznej sztuce zachodniej abstrakcji szukać można na marginesach przedstawienia w sztuce ornamentalnej, dekoracyjnej itp. To zaledwie kilka przykładów z wielu. W początkach nowożytności metafizyczną symbolikę czerni bada Robert Fludd; w jednym z traktatów metafizycznych z 1617 roku (Tractatus secundus de naturae simia seu technica macrocosmi historia), by zilustrować ciemność absolutną, użył figury czarnego kwadratu na białym tle, obwiedzionego z czterech stron napisem ,Et sic in infinitum”. W 1793 roku w Tristamie Shandym Sterne'a jako ilustracja pojawia się zagadkowa pięćdziesiąta siódma czarna strona (abstrakcyjny czarny prostokąt na białym tle), zaraz po okrzyku „O, biedny Yoricku!”. W 1840 roku satyryk Charles Amédée de Noé (o pseudonimie Cham) w Historii Pana Lajaunisse'a umieszcza humorystyczny rysunek prezentujący monochromatyczną fotografię czerni, a trzy lata

${ }^{19}$ Pliniusz Starszy, Historia naturalna, t. 2, tłum. I. i T. Zawadzcy, Wrocław 2004, s. 403. 
później francuski podróżnik, fotograf, rysownik, Charles d'Arnoux (o pseudonimie Bertall) w podobnie satyrycznym tonie komentuje malarski „efekt nocy” — obraz o tytule Vue de la Hougue (effet de nuit) „przedstawiać” ma przegraną przez Francuzów bitwę morską pod La Hogue. Wraz z francuskimi komikami pukamy już jednak do drzwi współczesności, stojąc u progu „właściwej” sztuki abstrakcyjnej — uważam jednak, że nie sposób dziś rozstrzygnąć, czy jej początki tonęły w oparach absurdu, czy lęgły się w powadze i mrokach metafizyki (czego najlepszym dowodem niech będzie anegdota wspomniana w przypisie siedemnastym).

Przykłady „pierwszych abstrakcji” (pierwszych dzieł abstrakcyjnych) można by mnożyć — od lat w osobnych folderach zatytułowanych „,zerń”, „biel”, „czerwień”, „błękit” itp. gromadzę pochodzące z różnych epok i miejsc okazy „sztuki abstrakcyjnej" - często równie kuriozalne co tu wspomniane, odnalezione nierzadko przypadkiem, niemieszczące się w historycznych kolekcjach itp. Bez wątpienia przyjmuję jednak, że do awansu przedstawień abstrakcyjnych, obecnych skądinąd w sztuce od wieków, przyczyniły się badania nad symboliką, znaczeniem, a następnie oddziaływaniem koloru — jako autonomicznego elementu kompozycji — na ciało, psychikę, uczucia i myśli odbiorcy, zapoczątkowane wprawdzie już w średniowieczu i podejmowane w nauce w traktatach optycznych i teoriach barw w wiekach XVII i XVIII, pogłębione jednakże w praktyce dopiero przez dziewiętnastowieczną psychologię eksperymentalną i teorię widzenia oraz przez równoległe eksperymenty z efektami barwnymi, prowadzonymi na mniej lub bardziej świadomym poziomie przez romantyków, symbolistów, impresjonistów i postimpresjonistów w drugiej połowie XIX wieku (Monetowskie i Turnerowskie pejzaże, wcześniej abstrakcyjne akcenty na czarnych obrazach Goi i wiele innych) oraz przez fowistów i ekspresjonistów w pierwszej połowie XX wieku, kiedy to ostatecznie ugruntowano autonomię barwy jako samodzielnej wartości i przedmiotu przedstawienia. Siłą rzeczy nie da się jednak wyczerpać rozległego zbioru wątków i tropów sztuki abstrakcyjnej, rozciągającego się, jak się wydaje, w nieskończoność — „et sic in infinitum”, by powtórzyć za Fluddem.

Jak już pisałam, od rozstrzygnięcia problemu historyczności abstrakcji (jest aczasowa, odwieczna bądź rodzi się w początkach dwudziestego wieku) zależy nasze podejście do jej odmian i możliwych typologii. Andrzej Turowski, analizując powstanie i rozwój abstrakcji w pierwszej połowie XX wieku, pisze o „dwóch drogach", czasami krzyżujących się, obrazowania bezprzedmiotowego, zmierzających w dwóch odmiennych kierunkach, symbolicznym i materialistycznym: „Z jednej strony przez »alogiczną« formę ku symbolice obrazu suprematystycznego, z drugiej zaś przez analizę języka plastycznego ku »materializmowi« przedmiotu konstruktywistycznego"20. Przy tym autor zdaje się sugerować, że sztuka abstrakcyjna swoje apogeum i najczystszą postać osiąga w malarskiej abstrakcji Malewicza, przypisując jej filozoficzną wręcz moc prezentowania istoty rzeczy:

Droga Malewicza, redukującego również warstwę przedstawieniową malarstwa do najprostszych form geometrycznych, do czerni i bieli, zmierzała do zagęszczenia uzasadnień teoretycznych dokonanej minimalizacji, o wyraźnie symbolicznym zabarwieniu. Suprematyzm, zdaniem Malewicza, i dzieło

${ }^{20}$ A. Turowski, W kręgu konstruktywizmu, Warszawa 1979, s. 68. 
sztuki bezprzedmiotowej sublimowało „bezprzedmiotową” istotę świata, rozumianego jako emanacja czystych wrażeń ${ }^{21}$.

Gdzie indziej sugerowałam też własną propozycję uporządkowania typów dwudziestowiecznej sztuki abstrakcyjnej, opartą na trzech rodzajach abstrahowania, stosowanych przez artystów awangardowych ${ }^{22}$. Proponowałam przyjąć, że sztuką abstrakcyjną pierwszej połowy XX wieku rządzą trzy „typy idealne” abstrakcji: po pierwsze, abstrakcja rozumiana jako (stopniowa) sublimacja formy czy struktury oraz myślenie figurami (pojęciami-obrazami), w tym ustanawianie (odkrywanie?) relacji bądź praw między nimi (proporcja, equilibrium, harmonia itp.). Po drugie, abstrakcja pojmowana jako konstrukcja, to jest wytwarzanie przedstawień niezależnych od wrażeń i spostrzeżeń (tu punktem wyjścia nie jest przedmiot, lecz idea, myśl). Wreszcie, abstrakcja jako źródłowa, czysta reprezentacja (na wzór Merleau-Ponty'ego koncepcji obrazowania jako aktu stawania się widzenia wraz z obrazem).

Procesy i rezultaty abstrahowania porządkowałam następująco: etap pierwszy (który umownie wyznacza drogę ku abstrakcji) stanowi „ekstrakcja” (abstrakcja sensu stricto, to jest uogólnianie bądź sublimacja wyglądu, jak Arnheima esencja czy istota lub Zekiego pojęcie wizualne), w której na drodze upraszczania („wyciągania") tego, co wspólne, powszechne, ogólne, odchodzimy od rzeczy konkretnej, od rzeczywistości spostrzeżonej, od wielości przedmiotów (ich „chaosu”) ku temu, co uniwersalne (ku kantowskiej idei estetycznej, choć niekoniecznie związanej ze wzniosłością).

Etap drugi (i zwrot abstrakcyjny) wyznacza ,konstrukcja” — sztuka staje się zupełnie nieprzedmiotowa i niemimetyczna, z założenia kontrze do rzeczywistości czy rzeczy w znanych nam (rozpoznawalnych) kształtach i konfiguracjach, a sam rezultat abstrahowania powstaje — jako ,konstrukt" — na drodze twórczej (swobodnej?) syntezy uproszczonych przedstawień.

Jako etap trzeci (podobnie, jak u Turowskiego, „najwyższy”) proponuję „re-prezentację", w której obraz rzeczywistości nie jest wtórny, naśladowczy względem niej, lecz alternatywny, symultaniczny, dopełniający itp.; przedstawienie rzeczywistości w fenomenologicznych ,języku/ mowie wysławiającej”, „prozie świata” czy „logosie zmysłowości”, które wracaja nas temu, co źródłowe (sprzed podziału na podmiot i przedmiot widzenia, doświadczania — jak napisałam) ${ }^{23}$.

Ilustracji do pierwszego typu abstrakcji (od redukcji szczegółowości i wielości do sublimacji tego, co istotne i ogólne) szukam w twórczości Klee - ewidentnego przykładu odchodzenia (ekstrahowania) od szczegółu do ogółu dostarcza seria obrazów: Czerwone drzewo, $1909>$ Szare drzewo, $1911>$ Kwitnaca jabłoń,

${ }^{21}$ Ibidem, s. 69-70.

22 Por. A. Bandura, Labirynty abstrakcji — od konstrukcji do reprezentacji, [w:] Dyskursy sztuki, dyskursy o sztuce, T. Pękala (red.), Lublin 2018, s. 115-134; A. Bandura, Abstrakcyjne wariacje na kształt. O procesach, zasadach i teoriach abstrahowania w percepcji zmysłowej, „Dyskurs. Pismo naukowo-artystyczne ASP we Wrocławiu" 18 (2014), s. 59-71; A. Bandura, Abstrakcja - między konkretem a idea, [w:] Ideo-metrie, Wrocław 2014, s. 19-24 n.

${ }^{23}$ Por. M. Merleau-Ponty, Proza świata. Eseje o mowie, tłum. S. Cichowicz, E. Bieńkowska, J. Skoczylas, Warszawa 1976; por. M. Dufrenne, Pour l'homme, Paris 1968. 
1912 > Kompozycja VII, 1913 czy (potraktowany już jako efekt finalny) Balet abstrakcyjny z 1937 roku. Theo van Doesburg mianował ten rodzaj abstrakcji „konkretyzacją myśli”, która czyni myśl widzialną. Sama nazwałabym ją wędrówką do punktu zero przedmiotu, do (istoty) rzeczowości (porównywanych do Kantowskich Dinge an sich).

Wasyl Kandyński tendencję tę traktował jako powszechną zarówno w sztuce, jak w przyrodzie, a w abstrakcji upatrywał początków awangardy i w wielu miejscach dawał dowody swemu przekonaniu, iż wraz z nią stajemy na progu nowej epoki:

To dążenie do elementarności jest mniej lub bardziej widoczne nie tylko w sztuce, ale w całym nastawieniu „nowoczesnego” człowieka, we wszystkich dziedzinach jego działalności; manifestuje się ono w przechodzeniu od form najprostszych do bardziej złożonych, które dokona się wcześniej czy później z całą pewnością. Sztuka abstrakcyjna, choć uzyskała autonomię, podlega jednak ,prawom natury”. Natura rozpoczęła skromnie od protoplazmy i komórek, by stopniowo dojść do do coraz bardziej skomplikowanych organizmów. Sztuka abstrakcyjna stwarza dziś podstawowe albo mniej więcej podstawowe, organizmy artystyczne [...] powątpiewający w w przyszłość sztuki abstrakcyjnej mają przed sobą jej stadium rozwojowe amfibii, której bardzo daleko jeszcze do wyższych kręgowców. Widzimy nie końcowy rezultat twórczy, lecz „sam początek",24.

Tusalava, abstrakcyjna animacja Lye'a z 1929 roku, podkreśla symbiotyczną relację sztuki i natury oraz fundamentalną wszechobecność abstrakcyjnych form w obu. W drugiej połowie XX wieku Mark Rothko (w eseju Particularization and Generalization), szukając podobieństw między sztuką a filozofią (i, równocześnie, różnic między sztuką a nauką — wzorem Arystotelesa dystynkcji poezja-historia, chciałoby się rzec), stwierdza: „A painting is a statement of the artist's notions of reality in the terms of plastic speech"25. Rudolf Arnheim, w kontekście abstrakcji (a czasami sztuki w ogóle), proponuje z kolei określenie „pojęcia wizualne” na powtarzające się w obrazowaniu „,wzorce kształtów” (nie konkretne kształty), pisząc, że „obdarzone są pewną ogólnością i łatwo je zidentyfikować”26.

Dalej, przykładów abstrakcji ,konstrukcyjnej” szukam u Klee, którego twórczości mottem głównym, począwszy od pierwszych abstrakcji aż po Confession créatrice, było „destruować z miłości do konstrukcji”, a sama konstrukcja opierać się miała na zupełnej destrukcji związków materialnych między częściami przedmiotu. Także w konstruktywizmie Rodczenki, twórcy obrazów „z namysłu”, nie z natury, zwanych „neoobiektywistycznymi”, tworzacymi ,sterylne”, to jest niezainfekowane wpływem rzeczywistości formy wypowiedzi artystycznej, samoistne gry linii, formy i barwy, proporcji, asymetrii, kontrastu, rytmu — w których nie znajdujemy „niczego »znanego «, niczego »zrozumiałego«" (jak o tego rodzaju sztuce abstrakcyjnej mawiała Warwara Stiepanowa). Sam Aleksander Rodczenko, podobnie jak

${ }^{24}$ W. Kandyński, Punkt i linia a płaszczyzna. Przyczynek do analizy elementów malarskich, tłum. S. Fijałkowski, Łódź 2019, s. 115.

${ }_{25}$ M. Rothko, The Artist's Reality. Philosophies of Art, Ch. Rothko (ed.), New Haven-London 2004, s. 22; s. 25: „He tries to give human beings direct contact with eternal verities through reduction of those verities to the realm of sensuality, which is the basic language for the human experience of all things".

${ }^{26}$ R. Arnheim, Myślenie wzrokowe, tłum. M. Chojnacki, Gdańsk 2011, s. 40. 
wcześniej Wasyl Kandyński, w abstrakcji widział znak nowych czasów ${ }^{27}$. Co ciekawe, nowe czasy wyrażaja się przez nowe środki wyrazu: fotografię i film. Rosyjski konstruktywista w tekście Fotografia-Sztuka z 1934 roku $^{28}$ to fotografii przypisuje funkcję uczenia „człowieka widzenia z nowych punktów”29. Nowe medium pełni rolę artystycznej formy kształcenia optycznej ekspresji i świadomości wzrokowej.

Przykłady fenomenologicznej „re-prezentacji” tropię w abstrakcji organicznej Arpa i Stażewskiego. W 1930 roku (w manifeście grupy Abstraction-Création) Hans Arp pisze: „Nie chcemy naśladować przyrody. Nie chcemy odtwarzać, chcemy tworzyć, podobnie jak roślina, która tworzy owoc, lecz go nie odtwarza. Chcemy tworzyć bezpośrednio, a nie pośrednio"30. Kreację zrównuje z abstrakcją, to jest dążeniem do- czy osiąganiem bezprzedmiotowości na drodze metamorfozy form wytworzonych przez człowieka (artefaktów) w formy naturalne, organiczne. Z tego powodu krytyczka sztuki Carola Giedion-Welcker w 1952 roku określi twórczość Arpa mianem ,formalnego elementaryzmu” i ,wegetacyjnego konstruktywizmu”31, stanowiącego symbiozę natury i architektury, przypadku i prawa.

W latach dwudziestych i trzydziestych XX wieku Henryk Stażewski podobnie dostrzega w abstrakcji „wynik wszechstronnego badania” rzeczywistości, widzenia i praw nimi rządzących ${ }^{32}$, a sztukę abstrakcyjną określa mianem „czystej plastyki”, która „ujawnia coraz inne prawa, rządzące wszechświatem, stwarza nową realność"33. Andrzej Turowski w eseju o Stażewskim z 1994 roku $^{34}$ napisze, że geometria umożliwiła mu ,niezwykłe ujęcie świata”, percepcję rzeczywistości (jako „plastycznego ekwiwalentu natury"), w której ,zwykły widok staje się niezwykłym"35, inaczej (fenomenologicznie rzecz ujmując) — alternatywną źródłową prezentację rzeczy, którą nasze widzenie niejako powołuje do istnienia (która staje się w widze-

27 W konspekcie przedmiotu „Konstrukcja” z 1921 roku w moskiewskim Wchutemasie czytamy: „Konstrukcja - to uporządkowanie elementów. Konstrukcja — to światopogląd naszych czasów.” (i dalej: „Wiedza, eksperyment... cel, konstrukcja, technika i matematyka — oto bracia i siostry naszych czasów.”) - cyt. za: G. Karginow, Rodczenko, tłum. M. Schweinitz-Kulisiewicz, Warszawa 1981, s. 88-89.

28 Cyt. za: ibidem, s. 227.

${ }^{29}$ A. Rodczenko, Drogi wspótczesnej fotografi, tłum. K. Frejdlich, „Obscura” 8 (1988), s. 31-32 (,trzeba fotografować zwykłe, dobrze znane przedmioty z całkiem nieoczekiwanych miejsc i w nieoczekiwanych pozycjach, a nowe obiekty z różnych punktów, dając pełne wyobrażenie o obiekcie").

${ }^{30}$ Cyt. za: Hans Arp i Polska, M. Smolińska i M. Steinkamp (red.), Poznań 2017, s. 54: „abstrakcja, ponieważ niektórzy artyści dzięki stopniowemu abstrahowaniu form natury doszli do sztuki bezprzedmiotowej. Kreacja, ponieważ inni artyści osiągnęli bezprzedmiotowość bezpośrednio dzięki koncepcji geometrycznej albo dzięki używaniu takich elementów, jak koło, powierzchnie, belki, linie itd., które tak czy inaczej określa się jako abstrakcyjne".

31 Ibidem, s. 26.

32 Cyt. za: H. Stażewski 1894-1988, Łódź 1995, s. 60: „Pokazanie istoty rzeczy, czyli to, co zamierzał naturalizm, jest nieosiągalne. Jedynym celem nowej plastyki abstrakcyjnej, jest wyrażanie praw, kierujaccych rzeczami i bytem. Taka plastyka jest realna i nie jest pozbawiona pierwiastka ludzkiego".

33 Cyt. za: ibidem.

34 A. Turowski, Dyskurs o Geometrii, Wolności i Rozumie, [w:] ibidem, s. 29-41.

35 Andrzej Turowski wtóruje w ten sposób samemu Stażewskiemu z 1929 roku: „motywem sztuki stają się kształty geometryczne i ich arytmetyczny stosunek wymiarowy. Pod zewnętrzną powłoką przedmiotu kryją się stosunki i proporcje kształtów i barw, które są wyrazem czystych i jedynych elementów plastyki, stanowiących żywą treść sztuki” (H. Stażewski, Sztuki plastyczne jako streszczenie zycia kulturalnego, [w:] H. Stażewski 1894-1988, s. 62). 
niu, podobnie jak tworzy się w nim podmiot widzący). Abstrakcja umożliwia organiczne zjednoczenie („organiczną jedność”) świata (rzeczy) i podmiotu widzenia.

\section{2 historia pewnej iluzji: nieprzedstawieniowość a puryzm}

W tekście z 1932 roku Henryk Stażewski podnosi kwestię autonomiczności abstrakcji (którą w humorystyczny sposób zilustrował w przywoływanym przeze mnie na początku obrazku Ad Reinhardt):

Publiczność zadaje sobie często pytanie, co dany obraz wyobraża. Pytanie takie jest wynikiem pewnego nałogu. Przyzwyczailiśmy się do konfrontowania tego, co na obrazie jest namalowane z przedmiotami otaczającymi nas w życiu. Stanowisko takie, do absurdu doprowadzone przez szkołę naturalistyczną, jest całkowicie błędne. Obraz nic nie wyobraża. Stanowi on zespół form, tak ułożonych na płaszczyźnie obrazu, ażeby oddziaływały one na widza jak akordy muzyczne działają na słuchacza. Co do tzw. piękna [...] dla nas istnieje tyle piękna, ile człowiek w naturze może go zauważyć i z natury wydobyć. Wobec tego pokazanie go uzależnione jest od możliwości subiektywnych. Możliwości te są różne w różnych epokach... ${ }^{36}$

Wątpliwość ta powraca niczym bumerang w wielu, kanonicznych już dla sztuki abstrakcyjnej, tekstach estetyków analitycznych: czy możliwa jest sztuka „czysta"?; czy skoro obraz niczego nie przedstawia, to również niczego nie denotuje?; czy może odwrotnie — właśnie owo „nic”, o którym jest obraz, kolokwialnie rzecz ujmując, jest przedmiotem przedstawienia, a obraz abstrakcyjny niczego nie przedstawiając, odnosi nas do pustki lub nicości (ewentualnie do tego, co nie istnieje, czego nie ma, co jest, ale inaczej, gdzie indziej itp.)?

Stanowisko estetyki analitycznej (Goodmana, Beardsleya, częściowo Scrutona i innych) w tej kwestii pozostaje, według mnie, niezmiennie w mocy: po pierwsze, puryzm w sztuce, także czy zwłaszcza abstrakcyjnej, włożyć należy między inne mity modernizmu, gdyż — po drugie - abstrakcja owszem jest nieprzedstawieniowa (abstrakcja niczego nie przedstawia, niczego nie wyraża itp.), ale i przedstawiająca (coś denotuje), i to w najbardziej podstawowym sensie. Wedle przygotowanego przez Goodmana dla oksfordzkiej encyklopedii Groove Art Online hasła abstrakcja nie jest obrazem czegoś („nie opisuje, nie obrazuje, nie przedstawia”), lecz „odnosi się bezpośrednio" (,refers directly by showing rather than saying, as by exemplifying patterns or expressing feelings”); jest wręcz „konkretna”37 (,the

36 Cyt. za: ibidem, s. 68-69.

${ }^{37}$ Por. w tymże haśle: „Since an abstract work is one without representation, or more generally denotation, the question naturally arises what an abstract verbal or linguistic work may be, a text that says nothing, a story that does not tell a story, a poem that does not speak of anything. Like a picture that does not picture, these works are deprived of a normal denotative function and refer directly by showing rather than saying, as by exemplifying patterns or expressing feelings. A curious anomaly arises here. Through the ambiguity in the use of »abstract «, extreme cases of this kind, such as a page of miscellaneous and irregularly distributed words, are sometimes called not »abstract « but »concrete «! For example, in Concrete poetry, »concrete « is used as opposed not to »abstract « as »non-representational « but to »abstract « as »repeatable« or »universal«. For a normal denotative text, whatever is spelt the same way in the same language, regardless of differences in fount, hand, size, colour etc., is another instance of the same work. On the other hand, a Concrete poem, an alphabet painting by Jasper Johns or an example of Chinese calligraphy is unrepeatable - the particular concrete object is

Studia Philosophica Wratislaviensia, vol. XV, fasc. 3 (2020)

(C) for this edition by CNS 
particular concrete object is the functioning symbol"); a ,abstrakcyjny" w tym rozumieniu to „powtarzalny” (repeatable) lub „powszechny” (universal) ${ }^{38}$.

Innymi słowy abstrakcja nie naśladuje, nie wykorzystuje, nie odsyła do rzeczy-przedmiotów (objects) znanych z codziennego doświadczenia czy funkcjonujących w otaczającej nas rzeczywistości - ma jednakże referencję czy, prościej, temat (subject $)^{39}$. Nawet w tak radykalnych przypadkach jak minimalizm — przykładowo Bella (,My works are about »nothing « and illustrate in the most literal sense »emptiness and lack of content «") — tematem pozostaje dosłownie „nic”, ,pustka i brak zawartości”40. Kontynuując wątek goodmanowski, można ogólnie przyjąć, że sztuka abstrakcyjna - tak jak sztuka w ogóle czy wszelka kulturotwórcza aktywność człowieka — polega na tworzeniu symboli (symbol-making), a jej wyjątkowość tkwi w tym, że spełnia niemożliwe - uszczegółowia czy konkretyzuje symbol (nierzadko pozbawiając go jakichkolwiek odniesień poza samym dziełem czy jego „próbką”).

Nelson Goodman we właściwy sobie sposób analizuje i tłumaczy wspomnianą przez Turowskiego różnicę między sztuką abstrakcyjną o aspiracjach „symbolicznych" (rozumienie symbolizacji jest u Goodmana bardzo rozległe i, krótko mówiąc, obejmuje każdy rodzaj odnoszenia $\operatorname{sie}^{41}$ ) i materialistycznych. Nie trywializuje ani wartości symbolicznej (jak wyżej) sztuki abstrakcyjnej, ani nie lekceważy jej realnego czy materialnego potencjału. Egzemplifikacja (jako „najczystsza” postać symbolizacji) w sztuce abstrakcyjnej kieruje naszą uwagę na najbardziej elementarne tworzywo sztuki bądź jego elementy — sztuka abstrakcyjna ,próbkując” rzeczywistość pozwala badać jej „czyste” (wyjęte z okolicznościowego kontekstu, oczyszczone z przypadkowych własności czy nieskażone subiektywnym nastawieniem podmiotu), podstawowe elementy. $W$ tym sensie abstrakcja może uchodzić za bardziej realną od tak zwanej rzeczywistości, będącej już zawsze podmiotową projekcją, ewentualnie korelatem aktywności podmiotu i rzeczy.

\section{3 ,rozmiar ma znaczenie” (gwałt na wyobraźni)}

\footnotetext{
jest to bowiem gwałt, jaki rozum zadaje zmysłowości tylko po to, by rozszerzyć jac i dostosować do swej właściwej (praktycznej) dziedziny i kazać jej skierować spojrzenie na nieskończoność, która jest dla niej bezdenną przepaścią ${ }^{42}$
}

\footnotetext{
the functioning symbol. Other objects, even if spelt the same way (where that term is applicable), are not instances of the same work but are different works".

${ }^{38}$ N. Goodman, Abstraction, [in:] Groove Art Online, N. Courtright (ed.), Oxford 2009-till now, https://doi.org/10.1093/gao/9781884446054.article.T000257 [dostęp: 20.09.2020].

39 Mark Rothko uważał, że nieobecność przedmiotu (subject) w malarstwie abstrakcyjnym świadczy wyłącznie o niedojrzałości artysty i o tym, że „nie ma on nic do powiedzenia” — por. idem, The Artist's Reality. Philosophies of Art, s. 81.

${ }^{40}$ Cyt. za: D. Marzona, Minimal Art, Köln 2004, s. 38.

${ }^{41}$ Por. N. Goodman, Kiedy sztuka?, [w:] idem, Jak tworzymy świat, tłum. M. Szczubiałka, Warszawa 1997, s. 71-86.

${ }^{42}$ I. Kant, Krytyka władzy sądzenia, tłum. J. Gałecki, Warszawa 1985, s. 164.
} 
Immanuel Kant w ostatniej Krytyce, badając sądy estetyczne i antynomię smaku, porównywał sąd o pięknie z sądem o wzniosłości, temu ostatniemu przypisując specyficzny rodzaj towarzyszącej mu przyjemności: rozkosz negatywną, będącą „gwałtem na wyobraźni", kiedy to umysł przyciągany jest i odpychany na przemian przez przedmiot (strzeliste szczyty górskie, bezdenne przepaści, oceaniczne odmęty, monumentalne katedry, przepastne szafy...), wobec którego nasza wyobraźnia (będąca, u Kanta, władzą „uzmysławiania”, to jest zmysłowego przedstawiania czy uobecniania sobie przedmiotu pod jego nieobecność) pozostaje bezsilna, a umysł — w podziwie i pełnym nabożności szacunku.

Z góry wyrażam skruchę wobec tych, którym wprowadzone przeze mnie porównanie kantowskiej wzniosłości i minimalistycznego hasła „size matters” wyda się zbyt dosłowne. Na swoje usprawiedliwienie mam fakt, że hasło to (najpełniej obecne w land art i instalacjach oraz rzeźbach minimalistów w latach sześćdziesiątychosiemdziesiątych XX wieku) przedstawiciele minimal art brali zupełnie na serio.

Robert Morris jako jeden z wielu minimalistów postulował „nieobrazowość” rzeźby (uwolnienie jej od wymogu reprezentacji) jako jej zasadniczy warunek ${ }^{43}$; jako jeden z pierwszych skonceptualizował natomiast postulat powiększenia rozmiaru minimalistycznej abstrakcji dla osiągnięcia efektu panowania przedmiotu nad podmiotem, obu na równi poddanych jak największej sile grawitacji: „Jednym z warunków poznania przedmiotu jest odczucie siły grawitacji działającej na niego w rzeczywistej przestrzeni" ${ }^{4}$. Preferował kształty i figury ( unitary forms, nierzadko zwielokrotnione w odbiciach lustrzanych) górujące nad widzem i otoczeniem zarówno prostotą, jak wielkością i ciężarem:

Prostota kształtu niekoniecznie równa się prostocie doświadczenia. Formy całościowe nie ograniczają ilości relacji. One je porządkują. Jeśli dominująca, hieratyczna natura formy całościowej funkcjonuje jako stała, nie znaczy to, że wszystkie te uszczegóławiające relacje skali, proporcji itd., są unieważnione. Są one raczej związane ze sobą bardziej spójnie i niepodzielnie. Powiększenie kształtu, tej jedynej najważniejszej wartości rzeźbiarskiej, wraz z większą unifikacją i zintegrowaniem każdej z innych istotnych wartości rzeźbiarskich, z jednej strony sprawia, że wieloczęściowe i złożone formaty dawnej rzeźby stają się zewnętrzne, z drugiej zaś, ustanawia nową granicę i nową wolność dla rzeźby ${ }^{45}$.

Jak wyżej, proste monumentalne bryły stawiać miały nowe, większe wymagania ludzkiej percepcji (w tym doświadczeniu zarówno przestrzeni, jak czasu) — angażować widza również motorycznie, haptycznie itp.: „Rzeczy charakteryzujące się monumentalną skalą nakładają na sposób ich uchwytywania więcej warunków niż przedmioty mniejsze od ciała, a mianowicie rzeczywistą przestrzeń — w której istnieją — i wymagania kinestetyczne dotyczące ciała"46. Powiększenie rozmiaru rzeźby czy instalacji ma znaczenie o tyle, o ile pozwala na zmianę utartych nawyków percepcyjnych a przede wszystkim punktu widzenia (doświadczania) dzieła z egocentrycznego na allocentryczny (taki, w którym głównym punktem odniesienia nie jest punkt widzenia podmiotu, lecz przestrzeń dzieła). Krytykując tradycyjną rzeźbę („prace artykułowane w ramach zamkniętych struktur"), Robert Morris tworzył dla niej

\footnotetext{
43 Por. R. Morris, Uwagi o rzeźbie. Teksty, tłum. różni, Łódź 2010, s. 15 n.

44 Ibidem, s. 16.

45 Ibidem, s. 19.

${ }^{46}$ Ibidem, s. 21.
} 
wielkowymiarową alternatywę: prace „operujące w otwartym »polu « sytuacji” — te pierwsze nazywał ,typami przestrzeni »rzeczownikowych «”, w odróżnieniu od ,wielkiego rozmiaru” i ,przestrzeni »czasownikowych «" abstrakcji minimalistycznej, które „przejmowały kontrolę" nad przebiegiem doświadczenia estetycznego i wymuszały na (biernym zazwyczaj) odbiorcy działanie, ruch itp. Taka alternatywa stanowiła zupełne odwrócenie tradycyjnej relacji widz-dzieło - przyjemność płynącą z obcowania z minimal art można porównać do kantowskiej rozkoszy negatywnej (płynącej z poddania, wymuszenia reakcji, niepewności odbiorcy czy braku komfortowej, zdystansowanej perspektywy, wreszcie decyzji, by na szali nowego przeżycia postawić wszelkie dotychczasowe przyzwyczajenia i doświadczenia).

„Podobieństwo odnajdujemy w geometrii, nie w sztuce"47 — abstrakcja (w rozmaitych opisanych tu odmianach) wydaje się albo zbyt prosta lub pozbawiona sensu (to dość powszechnie przyjmowana opinia), albo zbyt wymagająca, hermetyczna, nieosiągalna.

W tytułowym, powtórzonym właśnie, sformułowaniu pojawia się jeszcze jedno „wszystko albo nic": „wszystko" nauki i ,nic” sztuki — ,nic”, którego ukazania najbliżej jest właśnie sztuka abstrakcyjna. Wielkie „nic” Kleina, stanowiące według artysty etap wieńczący wszelką autentyczną twórczość - koniec i zarazem początek: „Only when an artist has the courage to dissolve into empty space, into the Void, will he be able to create something genuinely new, essential, yet undogmatic and potentially meaningful to all".

Czy Ad Reinhardt dobrze się bawił w roku 1943, gdy krystalizował się w nim pomysł monochromatycznych, abstrakcyjnych obrazów, a okres ten, w sporządzonym pod koniec życia curriculum vitae opatrzył krótkim wpisem: „1943 — Continues making paintings about nothing"? ${ }^{48}$ Czy abstrakcja może stanowić źródło satysfakcji, przyjemności? Jakiego rodzaju? Sensualnej, zwyczajnie zmysłowej, płynącej z prostego, niewymagającego doświadczenia elementarnych form i kolorów czy bioracej się z oszołomienia — optycznego bądź (co gorsza!) konceptualnego illinx, ewentualnie (najgorsze!) z głębi mistycznego przeżycia?

Niezmiennie stoimy wobec alternatywy: wszystko albo nic — obiektywny, boski wgląd w istotę rzeczy (tylko dla wtajemniczonych) bądź perwersyjna zabawa w klocki (tylko dla optycznych dewiantów).

\footnotetext{
${ }^{47}$ E. Chillida, Writings, s. 49.

${ }^{48}$ A. Reinhardt, Art-as-Art. The Selected Writings of Ad Reinhardt, s. 6.
} 


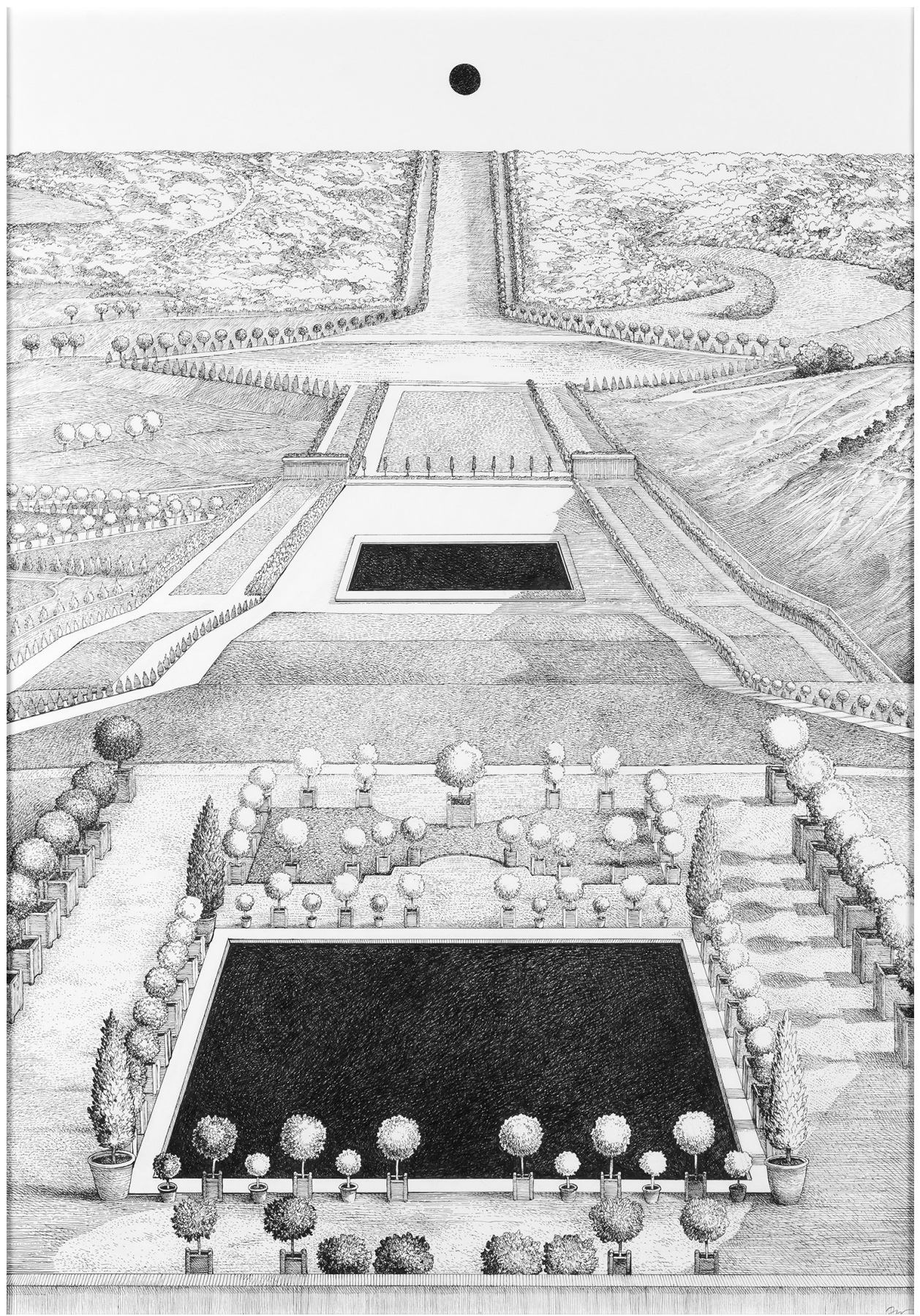

Jakub Woynarowski, Et sic in infinitum, 2014, tusz, papier, $100 \times 70 \mathrm{~cm}$, Kolekcja Fundacji Sztuki Polskiej ING, publikacja za zgodą artysty 


\section{Bibliografia}

Art-as-Art. The Selected Writings of Ad Reinhardt, B. Rose (ed.), Berkeley LA 1991.

Bandura A., Labirynty abstrakcji — od konstrukcji do reprezentacji, [w:] Dyskursy sztuki, dyskursy o sztuce, T. Pękala (red.), Lublin 2018, s. 115-134.

Chillida E., Writings, Düsseldorf 2009.

Dufrenne M., In the Presence of the Sensuous, transl. M.S. Roberts, D. Gallagher, Atlantic Highlands 1990.

Dufrenne M., Sztuka i natura, tłum. I. Wojnar, [w:] Antologia wspótczesnej estetyki francuskiej, I. Wojnar (red.), Warszawa 1980.

Goodman N., Kiedy sztuka?, [w:] N. Goodman, Jak tworzymy świat, tłum. M. Szczubiałka, Warszawa 1997, s. 71-86.

H. Stażewski 1894-1988, Muzeum Sztuki w Łodzi, Łódź 1995.

Hans Arp i Polska, M. Smolińska i M. Steinkamp (red.), Poznań 2017.

Kandyński W., Punkt i linia a płaszczyzna. Przyczynek do analizy elementów malarskich, tłum. S. Fijałkowski, Łódź 2019.

Kant I., Krytyka władzy sądzenia, tłum. J. Gałecki, Warszawa 1985.

Karginow G., Rodczenko, tłum. M. Schweinitz-Kulisiewicz, Warszawa 1981.

Langer S.K., Problems of Art, New York 1957.

Marzona D., Minimal Art, Köln 2004.

Merleau-Ponty M., Proza świata. Eseje o mowie, tłum. S. Cichowicz, E. Bieńkowska, J. Skoczylas, Warszawa 1976.

Morris R., Uwagi o rzeźbie. Teksty, tłum. różni, Łódź 2010.

Rothko M., The Artist's Reality. Philosophies of Art, Ch. Rothko (ed.), New Haven-London 2004.

Turowski A., W kręu konstruktywizmu, Warszawa 1979. 
